\title{
NAUJAUSI PAMINKLU巳 PAVIDALAI VILNIAUS MIESTO CENTRINĖS DALIES AIKŠTĖSE
}

\author{
Audrius Novickas \\ Architektūrinès grafikos katedra, Vilniaus Gedimino technikos universitetas, \\ Pylimog. 26/Traku g. 1, LT-01132 Vilnius, Lietuva, \\ El.paštasanovickas@takas.lt \\ Iteikta 20090527
}

\begin{abstract}
Santrauka. Analizuojamos pastarųjų 15 metų laikotarpio paminklų realizacijos ir konkursiniai projektai, skirti Gedimino prospekto aplinkoje Vilniuje esančioms aikštėms. Tyrimu siekiama atskleisti naujausių istorinės atminties ịprasminimo kompozicijų charakteringiausius meninès kalbos bruožus, jų įtaką šiuolaikinių visuomeninių erdvių formai ir turiniui, taip pat išryškinti sociokultūrinès aplinkos Lietuvoje poveikị paminklinei raiškai. Straipsnis pradedamas nuo trumpos paminklų Gedimino aplinkos aikštėse statymo istorinės apžvalgos, kontekstualizuojančios dabartinius Arkikatedros, V. Kudirkos ir Lukiškių aikščių memorialinius sprendinius ir jų projektus. Didžiojo kunigaikščio Gedimino, daktaro V. Kudirkos paminklai, Lukiškių aikštės sutvarkymo bei simbolio „Laisvė“ konkurso ir Sausio 13-osios memorialo projektiniai pasiūlymai nagrinėjami dèmesị kreipiant ị jų sąveikos su architektūrine ir urbanistine aplinka, vaizdinių, medžiagų bei technologijų semantinį aspektą. Remiantis atlikta analize daroma išvada, kad šiandieninè paminklinè raiška daugiausiai grindžiama konservatyviomis ideologinėmis nuostatomis, plètojama remiantis ịprastais galios ženklinimo sprendiniais ir vaizdiniais, tačiau tarp konkursinių projektų gausėja tokių, kuriuose įžvelgiamos paminklo sampratos ribų plètimosi ir inovatyvaus požiūrio ị visuomeninių erdvių kūrimą tendencijos.
\end{abstract}

Reikšminiai žodžiai: paminklas, aikštė, Vilnius, Gedimino prospektas, istorinè atmintis, ženklinimas, reikšmė, sociokultūrinis kontekstas, diskursas, naujausios tendencijos.

\section{Ivadas}

Atkūrus nepriklausomybę 1990 m. itin pagausèjo iniciatyvų sustiprinti memorialinę pagrindinių Lietuvos miestų aikščiu funkciją pastatant jose nacionalinès istorijos įvykių ir asmenybių paminklus. Nemaža dalis naujųjų istorinès atminties ịprasminimo sprendinių šiandien jau realizuota, dèl kitų vis dar polemizuojama, ieškant platesnio sutarimo ir politinès valios. Dabartinis paminklų statymo pakilimas yra snulemtas Lietuvos ankstesnès politinès raidos $\mathrm{XX}$ a. pertrūkių, deformacijų ir menkų ekonominių galimybių, dèl kurių kritinis kiekis paminklų nebuvo realizuotas praeityje. Vakarų valstybėse, skirtingai nei Lietuvoje ir kitose posovietinėse šalyse, monumentu statymo intensyvumas didžiausią pakilimą pasieké XIX a. pabaigoje ir XX a. pradžioje. XX a. antroje pusèje Vakarų šalyse išryškejo ne tik kiekybiniai, bet ir kokybiniai paminklinès raiškos turinio bei formos pokyčiai, paveikti visuomeninès sferos demokratizavimo ir šiuolaikinio meno raidos tendencijų (pasak A. Raven, šiandien meno visuomeninèms erdvèms $k \bar{u}$ rinys nebeasocijuojamas su raiteliu ant žirgo (1989)). Tačiau Lietuvoje ir Vakaruose vykstančių istorinès atminties įprasminimo procesų asinchroniškumas ne sumenkina, o tik aktualizuoja naujųjų lietuviškų paminklų meninės raiškos tyrimus. Jų tikslas išryškinti šio žanro vietinius ypatumus, tapatumą, jo santykị su ankstesnių laikotarpių užsakomųjų kūrinių, skirtų visuomeninèms erdvèms, tradicija ir dabarties socialiniu kultūriniu kontekstu.

Straipsnyje nagrinėjami paminklai, sukurti per pastaruosius penkiolika metu, ir konkursiniai projektai, skirti Gedimino prospekto ašyje esančioms aikštems. 
Konkrečios urbanistinès aplinkos pasirinkimą lemia tai, kad Gedimino prospektas yra viena svarbiausių Lietuvos sostinès gatvių, o jos ašyje esančios aikštès yra reikšmingos visos Lietuvos viešųų erdvių mastu. Tyrimo objekto aktualumą lemia ir tai, kad pastarojo dešimtmečio laikotarpiu Vilniaus savivaldybè, LR Vyriausybè, privatūs rèmèjai skyrè nemažai lèšų tiek Gedimino prospektui, tiek ir šalia jo esančioms aikštèms atnaujinti ir paminklams statyti, o iggyvendinti ženklinimai ir jų projektai susilauke tiek specialistų, tiek platesnès visuomenès dėmesio ir kontroversiškų vertinimų. Paminklų ir konkursinių projektų diskursyvia analize siekiama išryškinti memorialinių sprendinių būdingiausius meninès kalbos bruožus kaip prasmių kūrimo ir vertybių ženklinimo visuomeninèje erdvèje priemones. Siekiant šio tikslo dèmesys kreipiamas ì paminklų sąveikos su architektūrine ir urbanistine aplinka, vaizdinių, medžiagų bei technologijų semantinị aspektą. Realizacijų ir konkursinių pasiūlymų meniniai pavidalai nagrinėjami naujausius pavyzdžius lyginant su istoriniais, o lietuviškus su užsieniniais.

\section{Istorinis Gedimino prospekto viešųjų erdvių paminklinio ženklinimo diskursas}

Gedimino prospektas (skirtingais laikotarpiais turèjęs Šv. Jurgio, A. Mickevičiaus, J. Stalino, V. Lenino pavadinimus) XIX a. buvo pradètas formuoti modernaus miesto plètros kontekste. Vystyti miestą panaudojant iš Katedros aikštės veduokliškai išvedamų tiesių gatvių schemą dar $1817 \mathrm{~m}$. pasiūlè miesto architektai V. Guestis ir J. Poussier. Iki vienos ašinès gatvès supaprastintas šios koncepcijos variantas buvo pradètas realizuoti XIX a. viduryje, o šimtmečio pabaigoje prospektas tapo ryškiausiu naujojo miesto infrastruktūros formantu, kartu ir simboline galios ašimi. Prospekto ašyje Žvėryne $1903 \mathrm{~m}$. buvo pastatyta Dievo motinos Apreiškimo - Znamenskajos cerkvė, kuri uždarè prospekto ašies perspektyvą priešingame nei Katedra gale ir tapo katalikiškosios šventovès vizualine oponente. Prospekto ašies ideologinis poliarizavimas pasitelkiant sakralinius galios orientyrus bylojo apie šio infrastruktūros elemento išskirtinę svarbą simbolinio miesto teritorijos žymëjimo, jos pavertimo sava ir hierarchinių ryšių nustatymo taktikoje, panaudotoje carinès Rusijos valdžios ir stačiatikių bažnyčios. Prospekto kaip ritualinio kelio idèja buvo vystoma naudojant ir memorialinius ženklinimus šalia prospekto esančiose aikštėse. Daugeliu atveju istoriniai prospekto paminklai buvo kuriami kaip erdvès dominantès, ak- centuojančios geometrinị jos centrą. $1865 \mathrm{~m}$. dabartinès Savivaldybės aikštès vietoje buvusiame skvere buvo pastatyta Aleksandro Nevskio koplyčia, skirta $1963 \mathrm{~m}$. sukilimo numalšinimui atminti. Toje pačioje vietoje po Antrojo pasaulinio karo buvo įkomponuotas generolo I. Černiachovskio paminklas (skulptorius N. Tomskis). Lukiškių aikštès centre $1952 \mathrm{~m}$. buvo ikkomponuotas monumentas Leninui (archit. V. Mikučianis, skulpt. N. Tomskis).

Išilginėje aikštès ašyje dinaminès pusiausvyros taške paminklas buvo statomas tuomet, kai dèl aikštès fizinių parametrų ir architektūrinio konteksto komponuoti centre buvo netikslinga. Tokia kompozicine schema panaudota Katedros aikšteje 1902 m. statant paminklą Jekaterinai II. Tokiu komponavimu buvo siekiama revizuoti aikštès aplinkoje esančių simbolinių akcentų - aukštutinès pilies gynybinio bokšto ir Katedros - naratyvus, kurti alternatyvius „pasakojimus" (Novickas 2000). 1931 m. A. Mickevičiaus atminties ịprasminimo konkursą laimejjusio lenkų skulptoriaus $\mathrm{H}$. Kunos projekte paminklą buvo sumanyta pastatyti ne aikštejje, bet prospekto centrinejje ašyje. A. Mickevičiaus paminklą planuota atgręžti i rytus, t. y. į Katedros pusę. Jei pradètą kurti memorialinị sprendinị būtų pavykę iki galo igyvendinti, jis būtų gerokai pakeitęs Gedimino prospekto erdvinę ir simbolinę struktūrą. Aukščiausioje prospekto vietoje ¡komponuotas kūrinys turẻjo tapti svarbiausia vizualia dominante ir žvilgsnio kontrolès priemone. Aiškiai išreikštos priekinè ir nugarinė figūrinio paminklo pusès (Mickevičiaus žvilgsnis atgręžtas ị katedrą) tarsi būtų dalinusios prospektą ị dvi dalis - vertingesnę, esančią tarp jo ir katedros, ir mažesnès svarbos, liekančią už jo nugaros. Būtent nugarinè pusè turèjo būti atgręžta ị prospekto gale stovinčią cerkvę.

\section{Naujausių paminklų Gedimino prospekto aplinkos aikštėse meninių sprendinių analizė}

Didžiojo kunigaikščio Gedimino paminklas, pastatytas Arkikatedros aikšteje 1996 m. (skulpt. V. Kašūba, archit. H. K. Šilgalis), tapo pirmuoju stambiu memorialiniu sprendiniu prospekto ašyje esančiose visuomeninėse erdvėse atkūrus nepriklausomybę (1,2 pav.). Šis monumentas yra tik vienas iš pastaraisiais metais kintančio Arkikatedros aikštės pavidalo formantų, tačiau atsiradęs anksčiau, nei išryškejjo jos erdviniai tūriniai pokyčiai, nulemti naujos fizinès ir simbolinès dominantès - Valdovų rūmų (archit. R. Grigas, statomi nuo $2002 \mathrm{~m}$.) - ir dangos pakeitimo (archit. A. Katilius, J. Sazanovas, R. Bitovtas, 2000). Naujųjų 


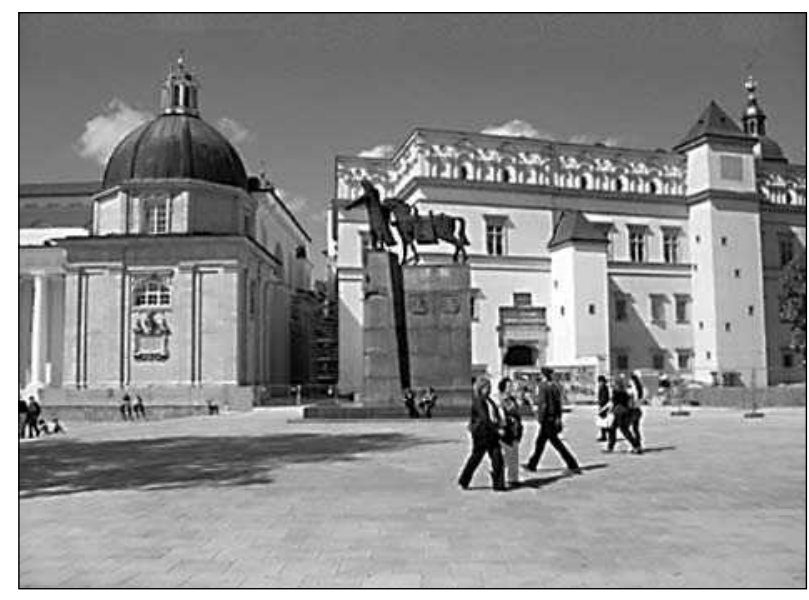

1 pav. Didžiojo kunigaikščio Gedimino paminklas Arkikatedros aikštèje (skulpt. V. Kašūba, archit. H. K. Šilgalis), 1996. Vaizdas iš šono

Fig. 1. Grand Duke Gediminas Monument on Arkikatedra Square, Vilnius (sculpt. V. Kašūba, archit. H. K. Šilgalis), 1996. Side view

Arkikatedros aikštès formantų chronologinè ir hierarchinè progresija nuo skulptūriniụ prie architektūrinių ir urbanistinių sprendinių leidžia manyti, kad Gedimino paminklo statymas buvo aikštès erdvès formavimo procesų atžvilgiu autonomiškas simbolinio vaizdinio kūrimo aktas. Paminklo integruotumo architektūrinèje aplinkoje ribotumą lèmè ir tai, kad lokalizuojant monumentą aikšteje bei orientuojant ji pagal pasaulio kryptis liko neišplètota kompozicinès sąsajos su Pilies gatve, pagrindine senamiesčio arterija ir viduramžiu Vilniaus plètros ašimi, galimybè. Tokią sąsają natūraliai suponavo paminklo, skirto miesto ¡kūrejjui ir valdovui, kuris religiniame centre įuria politinį centra - sostinę (Beresnevičius 1991), semantika. Paminklo komponavimas išryškinant vizualią jungti su pagrindine senamiesčio gatve būtų suteikęs galimybę iprasminti senojo miesto religinio ir politinio centrų dialektinị sąryšị. Tuo labiau kad paminklų kompozicinė sąsaja su svarbiomis ị aikštę įsijungiančiomis gatvėmis Vakarų šalių miestuose plačiai naudota nuo Renesanso epochos (del Santo aikštè, Paduja, del Sol aikštė, Madridas, Amalienborgo aikštė, Kopenhaga). Formaliu argumentu už monumento atgręžimą i pietu pusę galëjo būti ir numatomų statyti Valdovų rūmų kompozicinio ryšio su paminklu klausimas, keltas ir periodinèje spaudoje (Dumalakas 2008). Gedimino paminklo kūrèjai realizavo kitą nemažiau tradicinị kompozicinị sprendimą (pasak C. Sitte, raitelis ant žirgo gali būti komponuojamas arba paraleliai su aikštès

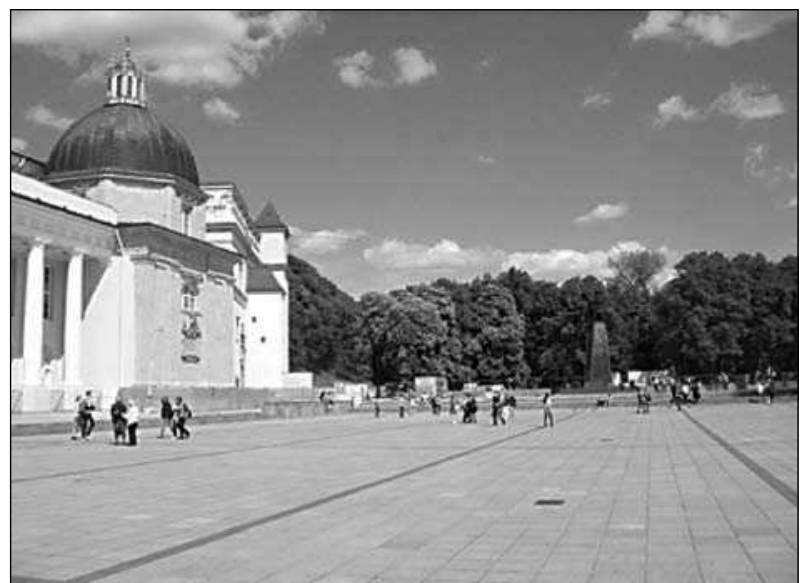

2 pav. Didžiojo kunigaikščio Gedimino paminklas Arkikatedros aikštèje (skulpt. V. Kašūba, archit. H. K. Šilgalis), 1996. Vaizdas išilginèje aikštès ašyje

Fig. 2. Grand Duke Gediminas Monument on Arkikatedra Square, Vilnius (sculpt. V. Kašǔba, archit. H. K. Šilgalis), 1996. View along longitudial axis of the Square

ašimi, arba paraleliai su pastato ašimi (Зитте 1993)). Paminklas buvo atgręžtas ị vakarus ir pastatytas rytinejje aikštės dalyje išilginèje jos ašyje. Tokią paminklo lokalizaciją ir orientaciją Katedros aikštèje pirmą kartą pasiūlè 1937 m. R. Gutas ir S. Bukovskis, numatydami vietą maršalo J. Pilsudskio paminklui pertvarkomos aikštės projekte. Iki 1939 m., kai Lietuva atgavo Vilnių, aikštès ir paminklo joje projektas nebuvo realizuotas. Katedros aikšte atnaujinta 1940-1942 m. laikotarpiu vadovaujant tuometiniam vyriausiajam Vilniaus architektui V. Landsbergiui-Žemkalniui. Renovuojant iš esmès remtasi R. Guto projektu, nors paminklo, tik jau ne J. Pilsudskiui, o kunigaikščiui Vytautui Didžiajam, realizacijos nesant politinių prielaidų ir buvo atsisakyta. Katedros aikštès sutvarkymo faktas tuo metu greičiausiai vertintas kaip simbolinès ir realios valstybès galios ịgyvendinti sumanymus įrodymas, aktualesnis už hipotetinę galimybę sukurti originalų lietuvišką projektą. V. Landsbergiui-Žemkalniui taip pat galejo imponuoti R. Guto siekis pertvarkyti aikštę i Tautos forumą, kurio viršutinè terasa, suformuota rytinèje aikštės dalyje, atliktų paminklo erdvès funkciją. Tautos forumo kompozicijoje menamas paminklas galejo tapti ne tik politinio tautos lyderio ženklinimu, bet ir erdvès dominante, išryškinančia trauką aikštèje iš vakarų ị rytus, kryptimi, lygiagrečia tai, kuria Katedros viduje judama nuo portalo link pagrindinio altoriaus. Toks sprendinys teikè prielaidas formuoti masinių žmonių sambūrių erdvę, kurioje nebūtų 
aiškios takoskyros tarp politinio ir religinio ritualu pobūdžio. Pastebėtina, kad 1937-ųjų paminklo projekte ižzelgiamą siekinį orientavimu ir lokalizacija akcentuoti sakralinę galios dimensiją daugiau kaip po pusšimčio metų pavyko išplettoti Gedimino paminklo kūrèjams V. Kašubai ir H. K. Šilgaliui. Gedimino kompozicine struktūra skulptoriui padiktavo svarbiausi architektūriniai aikštès akcentai - aukšta vienišo varpinès bokšto vertikale ir už jos didinga horizontali klasikine Katedra: taip atsirado stačias, miesta laiminantis kunigaikštis ir bütinas valdovo, karžygio atributas - žirgas. Šie du dèmenys panašiu ritmu pakartojo bokšto ir Katedros sugretinima (Kostkevičiūtè 1997).

Visuomenès vienybės idealo svarba nepriklausomybę atgavusioje Lietuvoje galëjo motyvuoti jo statytojus komponuoti Gedimino paminklą aikštès gilumoje, nes R. Guto pasiūlyta, o V. Landsbergio-Žemkalnio pradèta ir H. K. Šilgalio užbaigta realizuoti aikštès ir paminklo kompozicija buvo pagrista sociumo monolitinès visumos vizija ir žmonių mases orientuojančios erdvès kūrimo uždaviniu. Scenografiniai sprendimai šiandieninèje Arkikatedros aikštejje nacionalinių švenčių, tokių kaip Vasario 16-osios minèjimai, metu, kai scena statoma Gedimino paminklo papèdeje, demonstruoja pasirinktos kompozicijos funkcionalumą. Kita skirtingų laikotarpių meninių sprendinių tęstinumo priežastimi laikytina tai, kad atgimstančios Lietuvos valstybės ideologijoje tapatumo problema siejama su retrospektyvumu. Dabarties sprendiniai iteisinami ir aktualizuojami tiek, kiek jie susiję su praeities modeliais ir kiek juos atkartoja. Gedimino paminklo atveju retrospektyvumas laikytinas sąmoninga taktika, kurią taikant visuomeninëje erdvèje įvedama istoriniais orientyrais grịsta tvarka ir atliekamas grižimo it ikitrauminị (ikiokupacinị) istorijos tarpsnį aktas. Daugiau nei atsitiktiniu laikytinas faktas, kad buvo realizuotas būtent V. Kašubos kūrybinis sumanymas. Lietuvai praradus nepriklausomybę emigravęs ir sovietinių metų okupacijos nepatyręs skulptorius tapo selektyvių istorijos fragmentų simboline jungtimi, siejančia prieškarinę Respubliką su šiandienos Lietuva, praeiți ir dabartị, klasikinę tradiciją ir modernybę. Skirtingų epochų meninès raiškos modelių dermè charakteringa ir Gedimino paminklo vaizdiniams, stilistikai. V. Kašūba panaudojo klasikinę valdovo ir žirgo schemą, tačiau abi figūras išdèliojo beveik tame pačiame lygyje suteikdamas joms nehierarchišką santykị. Tiesa, valdovo ir žirgo figūrų santykio nehierarchiškumą anuliuoja visos paminklo kompozicijos vertikalumas - žvelgiant i j ji iš priekio ženklinimas labiau primena obelisko, o ne raitelio pavidalą. Gana manieringai apibendrintoje realistinèje raiškoje jaučiami XX a. ketvirto dešimtmečio tendencijų, pagrịstų kompromiso tarp modernistinès ir istoristinès formos traktuotès paieška, atspindžiai.

V. Kudirkos aikštė (dèl gausaus apželdinimo ir rekreacinès funkcijos joje gajumo turinti nemažai skvero bruožų) yra arčiausiai Arkikatedros aikštès esanti viešoji erdve prospekto aplinkoje, kurioje pastaraisiais metais iškilo paminklas. Kaip skveras su simboliniu (A. Nevskio koplyčia) arba realiu kapu (generolo I. Černiachovskio palaidojimas) ji formuota ir XIX, ir XX a. 2008 m. šioje visuomenineje erdveje iš dalies sumontuotas vieno iš XIX a. pabaigos - XX a. pradžios lietuvių nacionalinio atgimimo veikèjų daktaro V. Kudirkos paminklas (ji visiškai užbaigti planuojama 2009 m.) (3 pav.). V. Kudirkos aikšte buvo atnaujinta anksčiau, nei paaiškèjo paminklo konkurso nugalètojai ir jų siūlomi sprendiniai. Tai, kad $2003 \mathrm{~m}$. rekonstruojant aikštę (archit. V. Vizgirda) apsiribota jos kompozicijos iš esmès nekeičiančiais paviršiniais pokyčiais, tokiais kaip dangos, atraminių sienučių, aplinkos dizaino elementų medžiaginiu atnaujinimu, leidžia manyti, kad funkcijų plètros ir meninių pavidalu atitikties kintančiam sociokulturiniam kontekstui klausimai nebuvo keliami. Iš ankstesnių epochų paveldèta centriškai orientuota aikštès kompozicija išliko, ji nulèmè ir vietos, skirtos įamžinimo priemonei, nekintamumą. Panaudoję tamsesnès spalvos akmens inkrustaciją aikštės centrinèje dalyje projekto autoriai

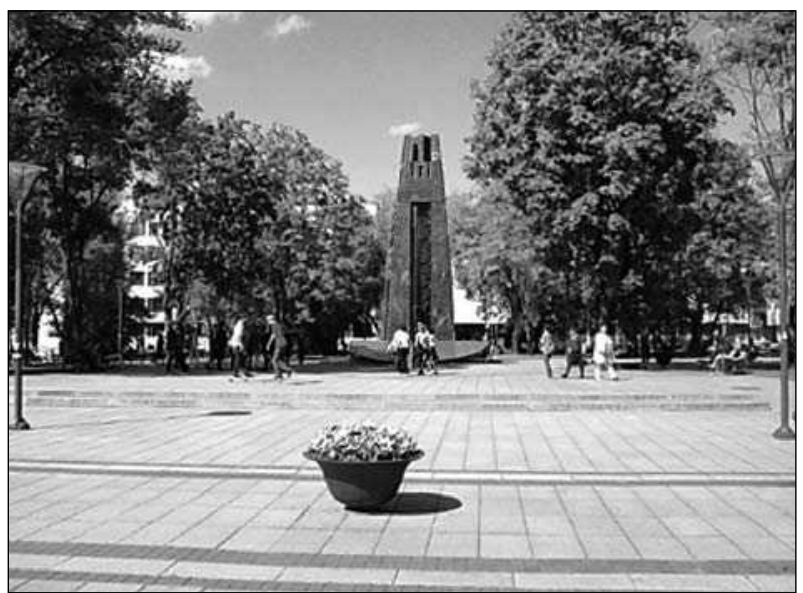

3 pav. Daktaro V. Kudirkos paminklas V. Kudirkos aikštejje (skulpt. A. Sakalauskas, archit. R. Krištapavičius), (nebaigtas, fotografuota 2009)

Fig. 3. Doctor V. Kudirka Monument (sculpt. A. Sakalauskas, archit. R. Krištapavičius) (unfinished) 
išskyrè rombo konfigūracijos zoną, kurioje turèjo būti statomas paminklas. Nors konkurso sąlygose buvo pažymètas konkretus necentrinis paminklo lokalizavimo taškas, vèlesni įvykiai parodè, kad nepaisant surašytu nuostatų, jis vis tiek buvo pastatytas vienintelëje logiškoje vietoje - rombo zonos viduryje.

V. Kudirkos paminklas atsirado dèl visuomeninès iniciatyvos, siejamos su Vilniaus medikų draugija. $2000 \mathrm{~m}$. ji ịsteigè Labdaros ir paramos fondą dr. Vinco Kudirkos vardui ịamžinti, kurio veikloje aktyviai dalyvavo ne tik gerai Lietuvoje žinomi medikai, bet ir kultūros, meno žmonès. $2002 \mathrm{~m}$. fondo steigèjams pavyko ịtikinti tuometinę Vilniaus savivaldybès valdybą, kad tinkamiausia vieta V. Kudirkos paminklui yra sostinès Savivaldybès aikštė, ir pasirašyti sutartị dèl leidimo statyti paminklą. Fondo paruoštose paminklo konkurso sąlygose (Kudirkos paminklo konkurso sąlygos 2002) buvo suformuluoti du esminiai reikalavimai:

1. Sukurti figūrinę kompoziciją, atspindinčią Vinco Kudirkos portreto bruožus.

2. Paminklo figūra ir architektūrinis sprendimas turi išreikšti Lietuvos himno dvasią (žmogaus ir tèvynès meilę, aukštus moralès principus, demokratizmą).

Sąlygų formuluotė byloja apie tai, kad užsakovai puoselëjo konvencionalaus lengvai suprantamo paminklo, kuriame realistiškai traktuojama figūra (kanoniškas vaizdinys) turètų architektūrinès simbolinès formos bruožų, viziją. Dėsningu laikytinas paminklo konkurso komisijos sprendimas nugalejjusiu projektu pripažinti A. Sakalausko ir architekto R. Krištapavičiaus kompoziciją. Skulptoriaus A. Sakalausko monumentali plastika dailètyrininkų apibūdinama kaip chrestomatinis neoklasicistinio mikèniškojo (turimas omenyje skulptorius J. Mikenas) modelio pavyzdys, kuris socrealizmo diktato metais atliko pozityvu vaidmenị išsaugojant gebejjimą dekoratyviai apibendrinti formas, tačiau neišvengè nuo aštuntojo $\mathrm{XX}$ a. dešimtmečio pasireiškusių manierizmo tendenciju (Jankevičiūtė 2004a). Šio modelio gajumą ir aktualumą ne tik sovietinès, bet ir postsovietinès Lietuvos visuomenineje sąmonèje, pasak dailès istorikès G. Jankevičiūtès, rodo ir tai, kad publika A. Sakalausko kūrinius ne tik palankiai vertina, bet net ima šlovinti labiau už jais pagerbtus asmenis (2004a). Vienu iš tokių teigiamai vertinamu paminklų pavyzdžių yra Antano Baranausko paminklas, pastatytas Anykščiuose 2003 m., kuris dèl analogiškos V. Kudirkos paminklui kompozicijos gali būti laikomas pastarojo variacija. Pats A. Sakalauskas A. Baranausko paminklo kompoziciją komentuoja taip: Neužteko vien figūros išraiškos, reikejjo sukurti ypatinga architektūrą. Paminklo dalimi tapo senaja Anykščiu barokine bažnyčia primenanti arka, kurioje esantis siluetas - aliuzija $j$ žemiškaja ir dangiškają tèvynę, užuomina ị dvasinę žmoniu giminystę, nematoma buvima šalia (Petraitienè 2004). Tai, ką A. Sakalauskas vadina Ypatinga architektūra, yra architektūrinio archetipo invariantai, tradiciškai naudojami kuriant monumentus. V. Kudirkos paminklo atveju architektūriniam kompozicijos elementui suteiktas varpinès bokšto pavidalas, artimas arkos vaizdiniui, panaudotam A. Baranausko memorialiniame sprendinyje. Tam pačiam archetipui, simbolizuojančiam Pasaulio ašį, Dievišką apsaugą, Nemirtingumą, Auką ir Atsinaujinimą, priskirtini ir piramidès, obelisko pavidalai. Visi pamineti vertikaliai orientuoti statiniai nuo seniausių laikų naudoti architektūroje sakralinei ir politinei galiai ženklinti. Varpinès bokšto vaizdini, panaudotą V. Kudirkos paminkle, galima lyginti su vienu svarbiausių tarpukario Lietuvos paminklu - 1922 m. V. Dubeneckio suprojektuota granito riedulių piramide su kovoje kritusius karius apraudančia lietuvaitę vaizduojančiu J. Zikaro bareljefu (4 pav.). G. Jankevičiūtè teigè, kad nepaisant kuklios išvaizdos bei nedidelio mastelio, kauniškis žuvusiuju už nepriklausomybę paminklas funkcija bei visuomeniniu statusu prilygo žymiausiems tuometinès Europos karo monumentams ir buvo gerbiamas taip pat, kaip Paryžiaus Žvaigždès aikštès Triumfo arka ar karaliaus Viktoro Emanuelio II paminklas Romoje (2004). Dailès

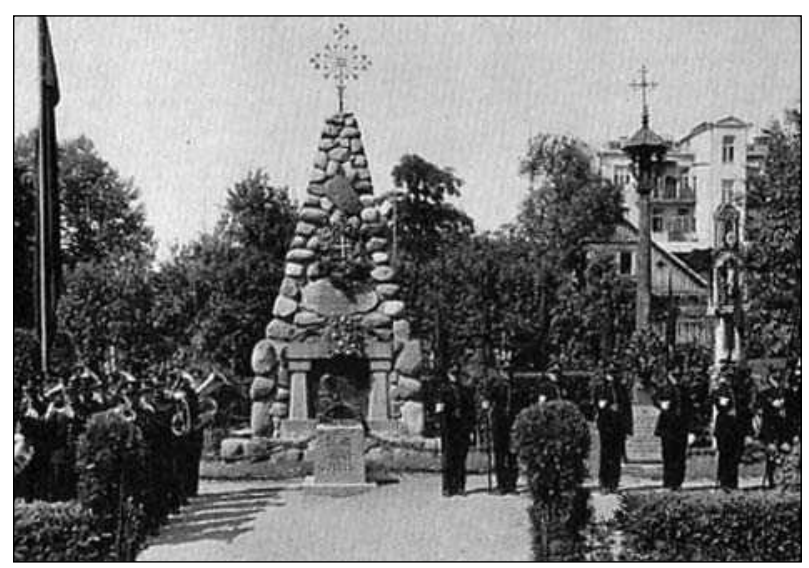

4 pav. Žuvusiems už nepriklausomybę paminklas Karo muziejaus sodelyje Kaune, 1921 (archit. V. Dubeneckis, skulpt. J. Zikaras)

Fig. 4. Monument to the Fallen for Independence in the garden of the War Museum in Kaunas, 1921 (archit. V. Dubeneckis, sculpt. J. Zikaras) 
istorikès paminètų vakarietiškų paminklų atvejais irgi panaudoti arkos, altoriaus architektūriniai pavidalai. Tačiau paminklo Karo sodelyje Kaune kompozicija pasižymejjo ir specifiniais meniniais sprendiniais, nebūdingais klasicizmo tradicija grịstiems Vakarų Europos, visų pirma Prancūzijos ir Italijos, paminklams. Jie pasireiške lauko riedulių naudojimu, liaudies meistrų darbo kryžių komponavimu piramidès aplinkoje, gausiu apželdinimu. Gamtiškumą, pagonišką panteizmą, kultūros liaudiškąias šaknis išreiškiantys sprendiniai byloja apie tautinio romantinio paminklo modelio paieškas. Analogiškos paieškos vyko prieškariu kaimynineje Lietuvai Vokietijoje, kur jau nuo XIX a. pradžios, oponuojant prancūziškajai paminklų tradicijai, vystyta Nacionalinio paminklo (Nationaldenkmal) koncepcija. Ji buvo išplètota XIX a. pabaigos - XX a. pradžios kaizerinio Reicho laikotarpiu ir nacistinès Vokietijos periodu ketvirtajame XX a. dešimtmetyje. Tiek Kaizerio Vilhelmo ir Bismarcho monumentuose, tiek ir vèlesniuose vadinamųjų mirusiųjų tvirtovių (Totenburgen) žuvusiems kariams projektuose atsiskleidžia būdingiausi vokiškojo romantinio monumento bruožai - komponavimas gamtinèje aplinkoje, grubiai tašyto akmens (granito ir smiltainio) naudojimas, su teutoniškąja mitologija siejamos viduramžiškai masyvios, tvirtoves primenančios architektūrinès formos. Pasak S. Michalskio, Bismarko monumentu stilistinio ir semantinio turinio evoliucija buvo nukreipta antiurbanistine, neopagoniška, antikultūrine ir neoprimityvistine kryptimi (1998). Pastebètina ir tai, kad dauguma vokiškų paminklų turejjo bokšto pavidalo struktūrą - B. Schmitz Porta Westfalica (1896 m.), Kyffhauser kalno Kaizerio Vilhelmo paminklas (1896 m.). XIX a. pabaigoje atsirado net atskiras monumento tipas, vadinamas Bismarko bokštu, kurio vienu žymiausių kūrèjų buvo architektas W. Kreis. Bismarko bokštų prieigos dažniausiai buvo apželdinamos ąžuolais, o jų viršūnėje ypatingų iškilmių proga deginti laužai.

Nepaisant užmojų skirtumų, visgi galima įžvelgti bendrumų tarp vokiškojo Nationaldenkmal pavidalų ir V. Kudirkos paminklo. Pastarajame irgi akcentuojamas bokštas, vainikuotas Gedimino stulpais. Šis valstybingumo ženklas konkrečioje memorialinèje kompozicijoje yra paverstas tvirtovès kuorų vaizdiniu, ženklinančiu paminklo gynybinę apsauginę funkciją (pasak E. Rindzevičiūtès, apsauga ir išsaugojimas akcentuojami visuose (Lietuvos) kultūros politikos dokumentuose (2005)). Tam tikros paralelès galètų būti ižzvelgiamos tarp Joninių laužų, naudotų Bismarko bokštuose, ir planuojamo Kudirkos paminklo apšvietimo, tarp fontanèlio, puslankiu juosiančio Kudirkos paminklo cokoli, ir chtoniniu konotaciju, S. Michalskio (1998) ižvelgtų germaniškuose paminkluose.

V. Kudirkos paminkle įžvelgiami romantiškai archajiški bruožai iš tikrųjų laikytini tik jo meninès formos ir reikšmių karkasu, kuris užpildomas ideologiniu ir stilistiniu modernizmo turiniu. Stilistinị turinị išreiškia XX a. būdingos technologijos ir medžiagos, tokios kaip stiklo plokštumos, noktiurninis apšvietimas, bokšto plieninę konstrukciją dengiančių akmens plokščių apdorojimas paverčiant jas kažkuo panašiu i plastiką. Šie sprendiniai rodo, kad paminklo kūrẻjams išorinis efektas buvo svarbesnis už natūralias medžiagų ir procesų savybes ir tarpusavio dermę. Kudirkos paminklo sprendiniuose pastebimas ir modernistinei raiškai būdingas autonomiškumas vietos ir erdvès atžvilgiu. Šiuos bruožus lemia tai, kad:

a) ịprasminantị objektą buvo nutarta pastatyti visuomeninèje erdveje, kultūriškai nesusijusioje su nacionalinio lietuvių atgimimo istorija ir konkrečiai su V. Kudirkos gyvenimu bei veikla, todèl nedarančioje principinès itakos paminklo suvokimui;

b) ekstravertiško tipo, t. y. dominuojančio ir fokusuojančio architektūrinès kompozicijos elemento funkciją galintis atlikti Kudirkos paminklas buvo ¡komponuotas gana intravertiškoje gausiai apželdinto skvero aplinkoje.

Lukiškių aikštè - didžiausia ir viena svarbiausių viešųjų erdvių prospekto aplinkoje, kurią nuo pat Lenino paminklo demontavimo $1991 \mathrm{~m}$. ruošiamasi pertvarkyti. $2008 \mathrm{~m}$. ịvyko Lukiškių aikštès suplanavimo ir simbolio „Laisve““ sukūrimo projekto konkurso pirmasis turas, o $2009 \mathrm{~m}$. pradžioje antrasis jo turas, kuriame dalyvavo septyni po pirmojo turo atrinkti kūrybiniai kolektyvai. Konkursas teikè galimybę užbaigti aikštės sutvarkymo ir simbolinių sprendinių joje paiešką, tačiau, kai konkursinių darbų vertinimo komisija neišrinko pirmos vietos verto projekto, jis tapo erdvės pertvarkymo idejų plètotės tarpine kulminacija.

Antrojo Lukiškių aikštės sutvarkymo ir simbolio „Laisvë“ konkurso ture dalyvavusius 7 projektus pagal jų meninị turinị ir santykị su architektūrine, urbanistine aplinka galima skirstyti $\mathfrak{i}$ tris grupes. Pirmai grupei priklauso projektiniai pasiūlymai, kuriuose derinami dominuojančio ir orientuojančio paminklo bruožai (UAB „Jungtinès architektų dirbtuvès" (archit. A. Nasvytis, O. Kiznytè, L. Krūgelis)) su skulpt. R. Midvikiu, konstr. T. Tubiu (5 pav.); Jono Anuškevičiaus PI „Archijonas“ (U. Krušinskienė, R. Puzinas, V. Izokaitis) su skulpt. D. Matulaite (6 pav.); 
K. Antanèlio, D. Regelskio, V. E. Čekanausko (7 pav.) komanda.

Dominantès tipo paminklais laikytini aikštę, kuri suvokiama kaip baigtinè (uždara) erdvinè tūrinè struktūra, fiziškai užvaldantys ženklinimai. Jie (arba svarbiausi jų elementai) komponuojami aikštès centre arba jos centrineje ašyje ties viena iš kraštinių. Šiam tipui priskirtinuose projektuose svarbiausiam memorialinès kompozicijos elementui dažniausiai suteikiami architektūriniai obelisko arba triumfo arkos pavidalai. Pasak A. Brinkmano, jau baroko laikotarpiu skulptūra taip nevertinta, kad taptu architektoniškai sutvarkytos erdves centrine dominante (Бринкман 1935). Architektūriniai pavidalai sudaro palankesnes sąlygas peržengti masto ribą, už kurios forma tampa Didelè (Koolhaas 1995), ir ịženklinti Centrą kaip susitikimą su galia, Mysterium magnum (Santarcangeli 1991). Naudojant dominantę kuriama monocentriška meninè visuma, leidžianti pajausti pasitenkinima baigtumu kaip bütinybe, turinčia sulaikomają galia, kuri neleidžia pasklisti galimybiu savivalei (Морозов 1999). Kita vertus monocentriškumas gali lemti aikštès monofunkciškumą, kurį K. Šešelgis pastebëjo Lukiškių aikštès centre ịkomponuoto Lenino paminklo atveju: kai aikštè tapo monumento erdve, kitos funkcijos liko antraeiless (Šešelgis 1997). Dominuojančiu paminklų struktūruojamos erdvès monocentriškumą lemia ir hierarchinis jos kompozicinio akcento bei papildančių struktūrinių elementų santykis. Vieni svarbiausių

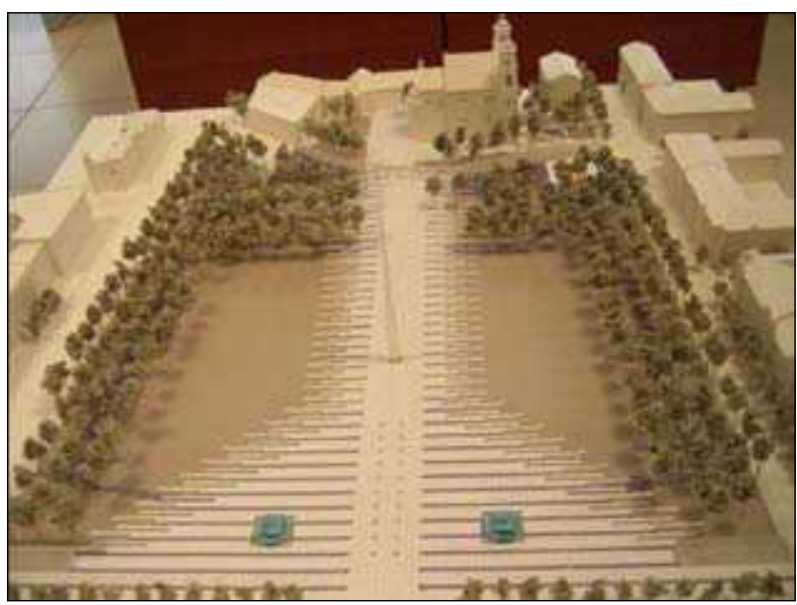

5 pav. Lukiškių aikštès sutvarkymo konkursinis projektas. UAB "Jungtinès architektų dirbtuvès"

(archit. A. Nasvytis, O. Kiznytè, L. Krūgelis) su skulpt. R. Midvikiu, konstr. T. Tubiu, 2009

Fig. 5. Lukiškès Square reconstruction competition. Project by UAB "Jungtinès architektų dirbtuvès" (archit. A. Nasvytis, O. Kiznytè, L. Krūgelis) with participation of sculptor R. Midvikis, constructor T. Tubis, 2009 papildančių struktūrinių elementų, pasikartojančių Lukiškių aikštės sutvarkymo dominuojančiam tipui priskiriamuose projektuose, yra ir vandens įrenginiai - fontanai (A. Nasvyčio, J. Anuškevičiaus kūrybinių komandų projektai), baseinas (K. Antanèlio komandos projektas). Obeliską ir fontaną derinančios kompozicijos naudotos nuo baroko epochos (Navonos aikštė Romoje, Šv. Petro aikštė Romoje, Santarvès aikštė Paryžiuje). Tokiame ansamblyje obeliskas, senovės egiptiečiams turèjęs saulès spindulio reikšmę, tampa

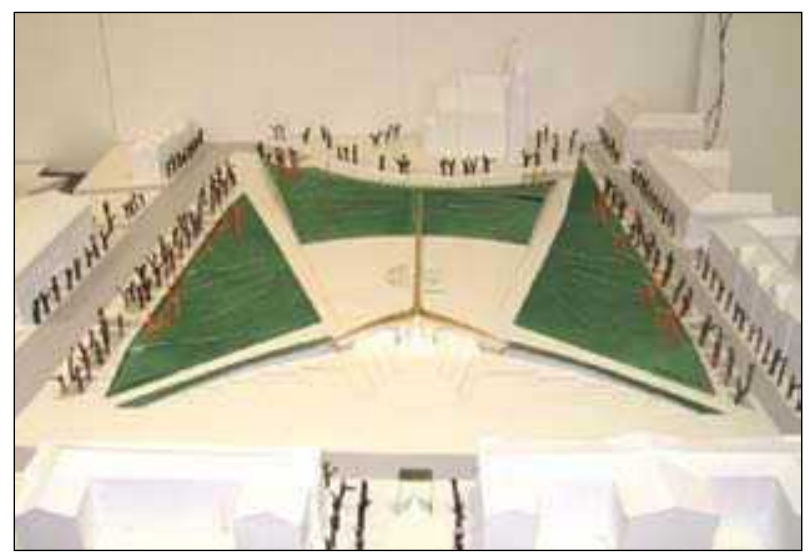

6 pav. Lukiškių aikštès sutvarkymo konkursinis projektas. Anuškevičiaus Pl „Archijonas“ (U. Krušinskienè, R. Puzinas, V. Izokaitis) su skulpt. D. Matulaite, 2009

Fig. 6. Lukiškès Square reconstruction competition. Project by Anuškevičius Pl̨ "Archijonas" (U. Krušinskienè, R. Puzinas, V. Izokaitis) with participation of sculptor. D. Matulaite, 2009

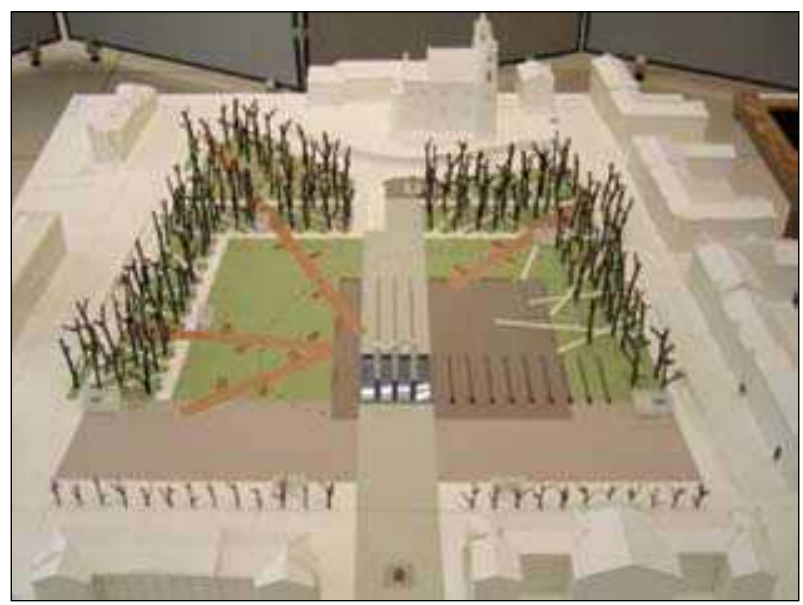

7 pav. Lukiškių aikštės sutvarkymo konkursinis projektas. K. Antanèlis, D. Regelskis, V. E. Čekanauskas, 2009

Fig. 7. Lukiškès Square reconstruction competition. Project by K. Antanèlis, D. Regelskis, V. E. Čekanauskas, 2009 
ugnies simboliu. G. Bachelardas teigia, kad vaizduote svajoja Kürima kaip artima ugnies ir vandens dvilypiu pradu sajunga (1993). Tačiau derinant obelisko ir vandens įrenginius (stovinčio vandens baseinas) ženklinama ne tik visa apimančių priešybių (vyriškojo ir moteriškojo, sakralaus ir profaniško pradų) jungtis, bet ir narciziškoji meilè savo atvaizdui kaip būdui suvokti galią ir intravertišką groži.

Orientuojantiems priskiriami paminklai, kuriais $\underset{t}{ }$ tam tikrą koordinačių sistemą jungiami vienas nuo kito nutolę urbanistinio audinio fragmentai. Trijuose minètuose Lukiškių aikštės ženklinimo projektuose vertikalūs memorialiniai akcentai komponuojami kaip sprendiniai, išryškinantys viena nuo kitos nutolusių Vilniaus centrinès dalies erdvių (Tauro kalno su ant jo stovinčiais Profsąjungų rūmais (Tautos rūmais ateityje?)) ir dešiniajame Neries krante esančios aukštuminès statybos plètros zonos („Urbanistinè kalvos“) ašinę sąsają, o kartu akcentuojantys skersinę Gedimino prospektui aši kaip esminị aikštės erdvės formavimo principą. Ašinę kompoziciją plètojančio ženklinimo probleminiu aspektu laikytina tai, kad formaliu pagrindu jungiami (kaip atitinkantys Vilniaus centrinès dalies urbanistinio karkaso pobūdị (Vyšniūnas 2007)) urbanistiniai fragmentai naratyviniu lygmeniu stokoja rišlumo. Ne vien formos, bet ir turinio aspektu analizuojant istorinius ašinių kompozicijų realizavimo pavyzdžius tampa akivaizdu, kad nuo pat pradžių deklaruojami jų skiriamieji bruožai - estetiškumas ir racionalumas - buvo neatsiejami nuo galios ideologijos principo, esminio realizuojant tiek utilitarius (kariniai ir socialiniai), tiek simbolinius (vaizdiniu ir vertybiu kontrolès ir ideologinès propagandos) miestų planavimo uždavinius (jèga ir valdžia išreiškiama tomis pačiomis priemonemis - ceremonialiu orientyru, ašine simetrija ir taisyklingu planu (Линч 1986)). Aptardama XVIII a. pabaigos - XIX a. Vilniaus planavimo koncepcijas I. Čiurlionienè pastebi klasicistinés universalijos neuniversalumo arba racionalumo iracionalumo paradoksa, kai universalija, kaip racionali funkcine schema, paneigia pati save dèl savo nefuncionalumo (2008). Pastebèti ašinių kompozicijų realizavimo paradoksai atskleidžia paprastais orientyrais pagristų urbanistinių schemų savitiksliškumą, jų atsietumą nuo realaus konteksto. Tačiau tai nèra tik tuometinio Vilniaus - imperijos provincijos centro - problema, kilusi dèl to, kad carineje Rusijoje miestai projektuoti pagal standartinius projektus - schemas, kurias ruošę inžinieriai dažnai net nebuvo detaliai susipažinę su formuojamu miestu (Čiurlionienè 2008). Chrestomatiniu ašinès kompozicijos išplètojimo pavyzdžiu laikytina ir pagal Hausmano projektą realizuota Paryžiaus infrastruktūros transformacija XIX a. antroje pusëje. Nagrinėdamas ši urbanistinị atveji L. Benevolo pastebèjo, kad norint nutiesti plačias ir tiesias gatves, reikèjo „nušluoti“ skurdžius kvartalus ir siauras gatveles, kur būriuodavosi revoliucingai nusiteikę gyventojai (1998). Pasak urbanistikos istoriko, nuo XIX a. šeštojo dešimtmečio prancūzų intelektualai iš esmès kritikavo Hausmano miesto taisyklingumą, simetriškumą (1998). Daugiau nei po šimto metų ta pačia galios ideologija paremtiems sprendiniams miestų planavimo teorijoje ir praktikoje prieštaravo ir Z $\mathrm{Z}$. Baumanas, teigdamas, jog svarbiausia gero miesto paslaptis yra jo teikiama žmonèms galimybè prisiimti atsakomybę už savo veiksmus istoriškai nenuspèjamoje visuomeneje, o ne sufantazuotame harmonijos ir iš anksto nustatytos tvarkos pasaulyje (2002).

Antrajai Lukiškių aikštès sutvarkymo ir memorialinio ženklinimo projektų grupei priskirtinos papildančio tipo kompozicijos (R. Paleko ARCH studija (arch. R. Palekas, skulpt. T. Gutauskas, A. Brazauskaité, M. Zemlickaitė, A. Palekienė, B. Puzonas, G. T. Gylytė, L. Sužiedelytė, M. Šiupšinskas, D. Zakaitė, M. Petrošius, A. Barzda (8 pav.)), Š. Kiaunès projektavimo i̇monè (arch. Š. Kiaunè, R. Raslavičius) (9 pav.). Papildančiais vadinami netoli aikštę ribojančių architektūrinių dominančių ir kitų svarbių jos aplinkos struktūrinių elementų komponuojami paminklai. Šis memorialinių kompozicijų tipas laikytinas vienu seniausių, tą patvirtina ir K. Sitte teigdamas, kad Romos imperijos forumu erdve büdavo paliekama laisva, o kraštuose užpildoma didesnemis ir mažesnèmis skulptūromis (Зитте 1993). Papildantys paminklai sudaro sąlygas išryškinti ir struktūruoti aikštès erdvę, horizontaliais ryšiais susieti ir integruoti struktūrinius jos komponentus. R. Paleko ARCH studijos aikštess sutvarkymo projekto paminklinis akcentas - vingiuojanti atminties siena, komponuojama išryškinant jos sąsają su Gedimino prospektu. Tam pasitarnauja sienos lokalizacija išilgai aikštès kraštinès, besiribojančios su prospektu, horizontalios ašies akcentavimas, kreivaeigis sienos planas, kontrastuojantis su magistralinès gatvès tiesumu. Š. Kiaunès projekte memorialinis akcentas, susidedantis iš horizontalios memorialinès plokštumos, peraugančios i vertikalią stelą, komponuojamas buvusioje KGB (dabar LR konstitucinis teismas) pastato centrinèje ašyje ir jo fizinès traukos zonoje. Abiejų projektų autoriai aikštę interpretuoja kaip vidinę miesto erdvę, todèl neplètoja už jos (nereikalinga) ribų nusitęsiančių ašių. Visas dèmesys tiek R. Paleko, tiek Š. Kiaunès projektuose sutelkiamas ị erdvès zonavimą atskiriant memorialinę 
(santykinai nedidelę) aikštės dalị nuo likusios erdvės. R. Paleko projekte likusiai aikštės daliai siūloma suteikti rekreacinę paskirtị paverčiant ją laisvo suplanavimo skveru. Š. Kiaunès projekte už memorialinès zonos ribų esančią erdvę raižantys takai byloja apie tranzito infrastruktūros joje plètojimą, tačiau iš esmès nesprendžia funkcijų gausinimo aikštèje problemų. Vis tiktai

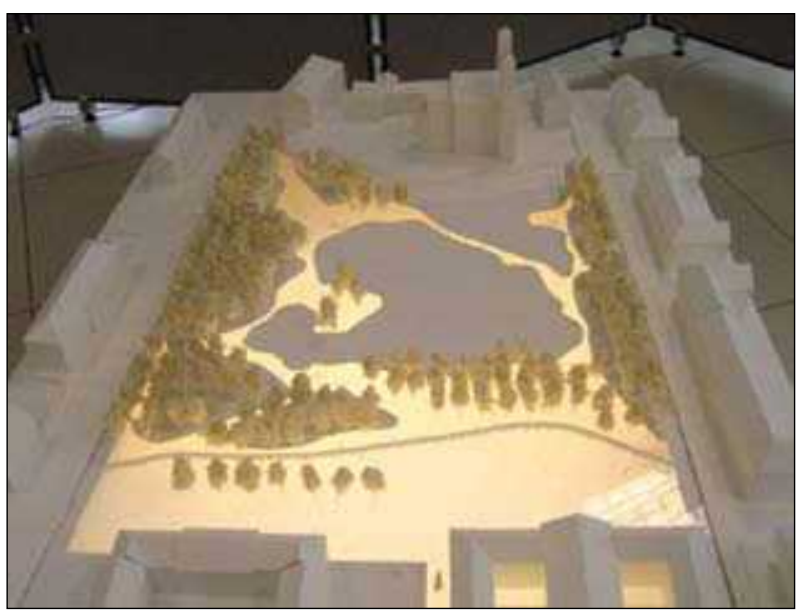

8 pav. Lukiškių aikštės sutvarkymo konkursinis projektas, R. Paleko ARCH studija

(arch. R. Palekas, skulpt. T. Gutauskas, A. Brazauskaitè, M. Zemlickaitè, A. Palekienè, B. Puzonas, G. T. Gylytè, L. Sužiedelytè, M. Šiupšinskas, D. Zakaitè, M. Petrošius, A. Barzda), 2009

Fig. 8. Lukiškès Square reconstruction competition. Project by R. Palekas ARCH studio (archit. R. Palekas, sculpt. T. Gutauskas, A. Brazauskaitè, M. Zemlickaite, A. Palekienè,

B. Puzonas, G. T. Gylytè, L. Sužiedelytè, M. Šiupšinskas,

D. Zakaitè, M. Petrošius, A. Barzda), 2009

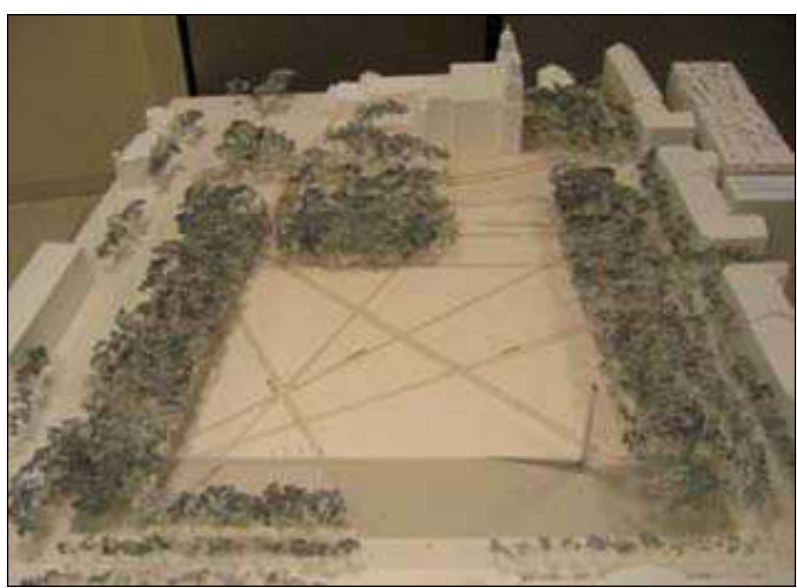

9 pav. Lukiškiu aikštès sutvarkymo konkursinis projektas, Š. Kiaunės projektavimo įmonè (archit. Š. Kiaunè, R. Raslavičius), 2009

Fig. 9. Lukiškès Square reconstruction competition. Project by Š. Kiaunè architects (arch. Š. Kiaunè, R. Raslavičius), 2009 abiejuose projektiniuose pasiūlymuose memorialinis akcentas panaudotas kaip dvigubos paskirties sprendinys, vienu metu atliekantis tiek aikštės kompozicinio ir funkcinio skaidymo, tiek ir atskirų zonų jungimo funkciją. Tai ypač būdinga R. Paleko ir T. Gutausko pasiūlytai kiauraraštei atminties sienai, kurioje išpjautos žmogaus figūros siluetus primenančios angos leidžia atsirasti ne tik vizualinèms atskirų aikštès zonų sąsajoms, bet ir suteikia galimybę pereiti iš vienos dalies i kitą. Toks meninis sprendinys išreiškia gyvų patirčių ir nuotaikų erdvių kūrimo idèjas, plètojamas Vakarų šalių miestuose pastaruoju laikotarpiu, kai, pasak G. Marling, ypatingas demesys skiriamas projektams, integruojantiems patirtis, laisvalaikio praleidimo formas ir pažinima (Marling 2008). Svarbu ir tai, kad siena priskirtina kitam vaizdinių tipui nei obeliskai ir triumfo arkos, nes ji konotuoja ne tiek galią ir transcendentalią tvarką, kiek žmogiškosios tvarkos kūrimą ir apsaugą. Sienos vaizdinio asociacinio lauko sklaidą žmonijos kultūros raidoje veikè tai, kad ji buvo vienu svarbiausiu senojo miesto struktūrinių komponentų, o tokie fenomenalūs architektūriniai objektai kaip Didžioji Kinų siena ir Raudų siena Jeruzaleje prisidejo prie Sienos tapsmo ne tik apsaugą, galią bet ir atmintí, sakralumą ženklinančiu vazdiniu. Šiuolaikiniuose memorialuose atminties sienos vaizdinys naudojamas gana dažnai, pvz.: Vietnamo karo veteranu memorialas Vašingtone (Maya Lin, 1982), Sol Lewitto Juoda forma, dedikuota žuvusiems žydams (Hamburg-Altona, Respublikos aikštė, 1989), Varšuvos sukilimo muziejaus kiemelio sprendiniai (archit. W. Obtulowicz, 2005). R. Paleko ARCH studijos projekto išskirtiniu bruožu laikytinas sienos kiauraraštiškumas, leidžiantis paversti sieną socialinès erdvès metafora.

Likę du antrajame Lukiškių aikštės konkurso ture dalyvavę autorių kolektyvų - UAB „Dviejų grupe““ (L. Tuleikis, K. Vaikšnoras, P. Vaitiekūnas kartu su skulptoriais R. Antiniu ir K. Lanausku) (10 pav.) ir M. Maziliausko su UAB „P.A.R.Y.Ž.I.U.S“ (11 pav.) projektai priskirtini inversinių paminklų (lot. inversio apversti) arba kontrapaminklų (Counter-Monuments) (Young 1992) tipui, atsiradusiam XX a. 9 dešimtmetyje, maždaug tuo pačiu metu, kaip ir intervencinio pobūdžio šiuolaikinio meno kūriniai architektūrinèje aplinkoje (instaliacijos, intervencijos, žemès meno kūriniai, performansai, akcijos), ir ryškiausiai atspindinčiam naujausius visuomeninių erdvių ženklinimo pokyčius. Tarp ryškiausių užsieninių šio tipo monumentų paminètini Vietnamo karo veteranų memorialas Vašingtone (Maya Lin, 1982) ir „Atminties laukas“ Berlyne (P. Eisenman, skulpt. R. Serra, 2005) (12 pav.). 


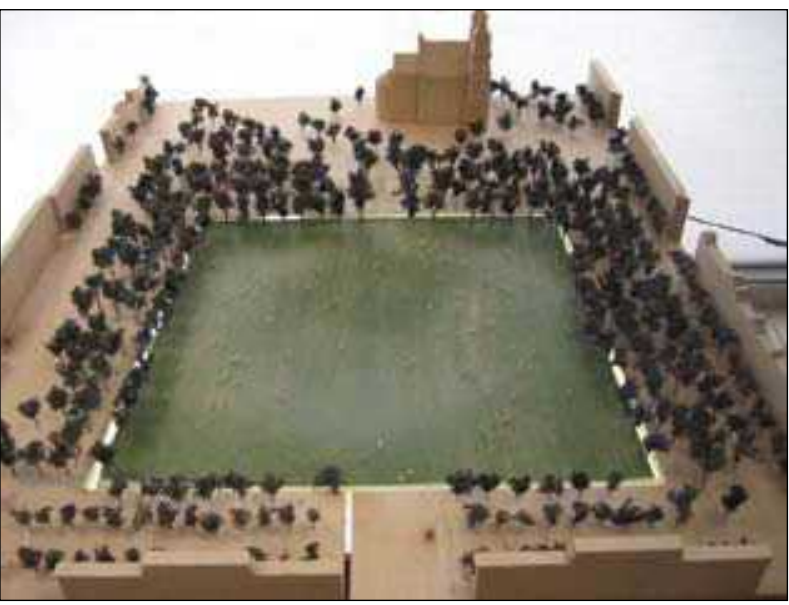

10 pav. Lukiškių aikštès sutvarkymo konkursinis projektas, UAB „Dviejų grupè" (L. Tuleikis, K. Vaikšnoras, P. Vaitiekūnas kartu su skulptoriais R. Antiniu ir K. Lanausku, 2009)

Fig. 10. Lukiškès Square reconstruction competition. Project by UAB “Dviejų grupè” (L. Tuleikis, K. Vaikšnoras, $P$. Vaitiekūnas with participation of skulptors R. Antinis ir K. Lanauskas, 2009

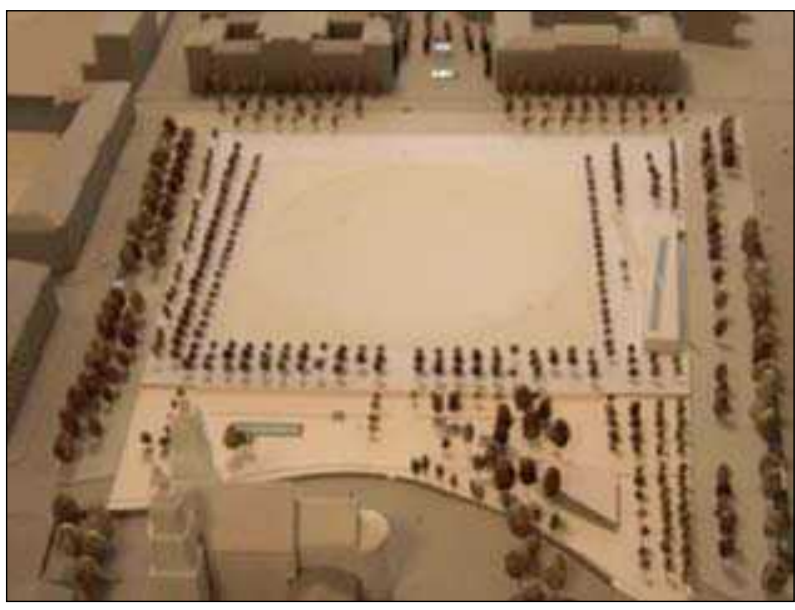

11 pav. Lukiškès aikštės sutvarkymo konkursinis projektas, M. Maziliauskas su UAB „P.A.R.Y.Ž.I.U.S“, 2009

Fig. 11. Lukiškès Square reconstruction competition. Project by M. Maziliauskas with participation of UAB “P.A.R.Y.Ž.I.U.S”, 2009

Su minètais paminklais „Dviejų grupès“ (dalyvaujant R. Antiniui) ir M. Maziliausko projektinius pasiūlymus sieja tai, kad juose ne tik atsisakoma tūrinių dominančių, bet ir visa aikštė formuojama kaip skulptūra arba žemès meno kūrinys. Iprasminti atmintị ir laisvès kovų idèją abu Lukiškių konkurse dalyvavę kūrybiniai kolektyvai siūlo performuojant aikštės reljefą, suteikiant jam koncentriškos įdubos pavidalą (M. Maziliausko projekte visa aikštės plokštuma pirmiausiai užkeliama

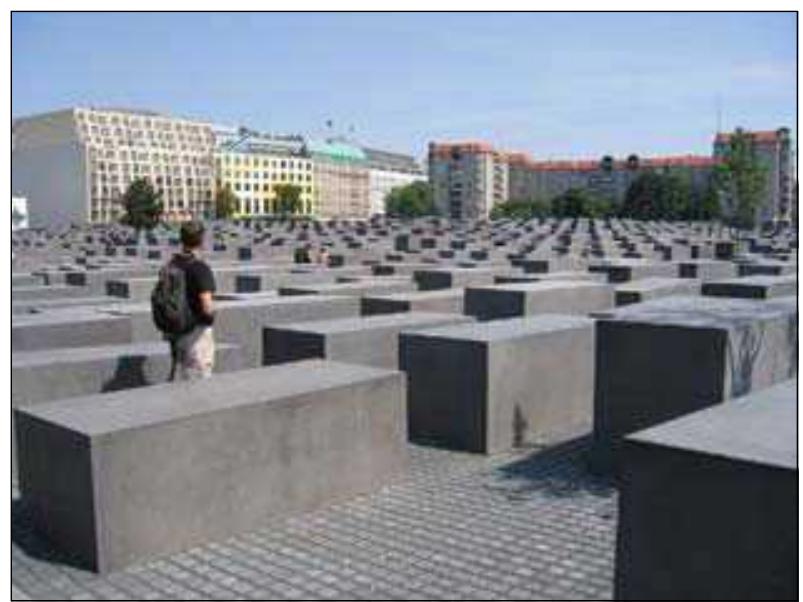

12 pav. "Atminties laukas" (nužudytų Europos žydų memorialas). Peter Eisenman dalyvaujant skulptoriui R. Serra, Berlynas, 2005

Fig. 12. Field of Memory (Memorial to the murdered Jews of Europe). Peter Eisenman with participation of sculptor R. Serra, Berlin 2005

ant marmurinio stilobato). „Dviejų grupès“ dalyvaujant R. Antiniui projekte minusinès altitudès aikštès reljefe papildomai panaudojamos ir per jos perimetrą formuojant ritualinị „Švino kelią“. Atsisakant arba minimalizuojant tūrinius formantus (M. Maziliausko projekte lieka paviljonas aikšteje ir koplyčia Aukų gatvės zonoje) ir igilinant reljefą išryškinamas erdvès pozityvas, kuris nulemia ne tik kiekybinius, bet ir kokybinius aikštès parametrus. Koncentriška įduba aikšteje modeliuojama kaip simbolinis indas, t. y. apglébianti, sukaupianti ir sauganti terpè. Kita vertus, „Dviejų grupès“ projekte, kuriame siūloma igilinti aikštę per 7 metrus, įduba gali virsti savotišku amfiteatru, o i ją nusileidę lankytojai - voajeristinès scenos veikejjais (analogiškai aplinką kūrè B. Nauman 2007 m. Miunsteryje realizuotame šiuolaikinio meno kūrinyje „Ispausta aikštë“, kuriame analizuojamas erdvès ir jos suvokejo santykis (13 pav.)). Svarbu ir tai, kad šiuose beveik nematomų paminklų projektuose ịduba nèra vien vidinis aikštes kompozicijos sprendinys, bet ir menine priemonè, kuria ịprasminamas dialektinis jos ir urbanistinio, gamtinio konteksto ryšys (Tauro kalnas ir viršutinè naujamiesčio terasa - pozityvas, aikšte slènyje - negatyvas). Vis tiktai išoriško panašumo nestokojantys „Dviejų grupès“ su R. Antiniu ir M. Maziliausko projektai pasižymi ir principiniais skirtumais. M. Maziliauskas projektuoja erdvę - monumentą, kuri didžiausią íspūdị turètų kelti žvelgiant ị ją tarsi i paveikslą, t. y. iš šalies (nuo aikštės paribių). „Dviejų grupès“ su R. Antiniu 


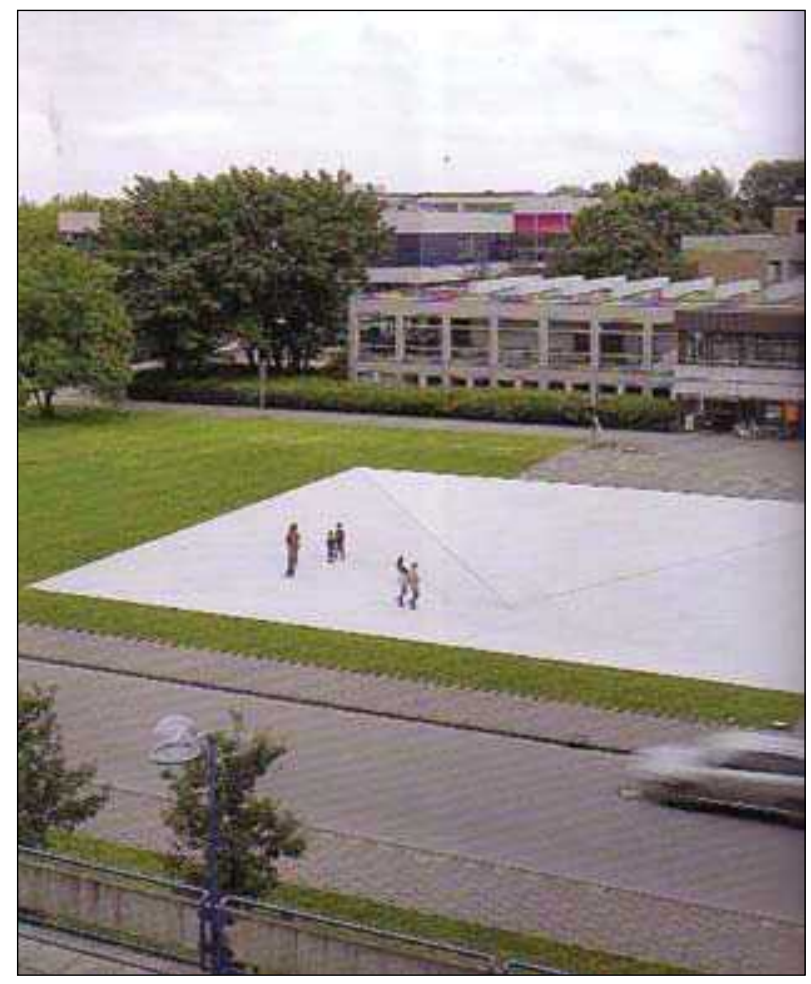

13 pav. „Aikštès ispaudimas" (Square Depression). Bruce Nauman, Miunsteris, 2007

Fig. 13. Square Depression by Bruce Nauman, Muenster, 2007

projektas, projektuojamas kaip intensionali squeikos tarp suvokéjo ir aplinkos erdvè (Winskowski 2007), kuri patiriama tik joje būnant ir apeinant tarsi kryžiaus kelio ceremonijoje. Vis tiktai abiem projektams būdingas vizualinių priemonių saikingumas, pasakojimo atsisakymas, abstrakčių formų, integruotų į aikštes reljefą, naudojimas. Apskritimo ir kvadrato pavidalų kombinacija, atsiskleidžianti per aikštes reljefo plastiką ir medžiagas, panaudota kaip socialinès koherencijos, bendrumo temos, „Centro“ archetipo, dvasinès ir materialios sąsajos ženklinimo priemonè. Tai meninès kalbos, kuriai daugiau analogu galima rasti šiandienos tarptautiniame nei Lietuvos kontekste (išskyrus R. Antinio Kaune realizuotą R. Kalantos paminklą), požymiai, bylojantys apie siekimą pasiūlyti netradicinio paminklo sampratą.

Šiaurès vakaruose Gedimino prospektas baigiasi ties Nepriklausomybės aikšte, kurioje šalia Seimo rūmų $2008 \mathrm{~m}$. buvo pastatytas dar vienas memorialinis objektas - Sausio 13-osios memorialas (UAB Vilniaus architektūros studija, archit. K. Kisielius ir J. Dagelis) (14 pav.). Jo autorių tikslas buvo kurti architektūrinę kompoziciją, apsaugančią autentiškų gynybinių įtvir-

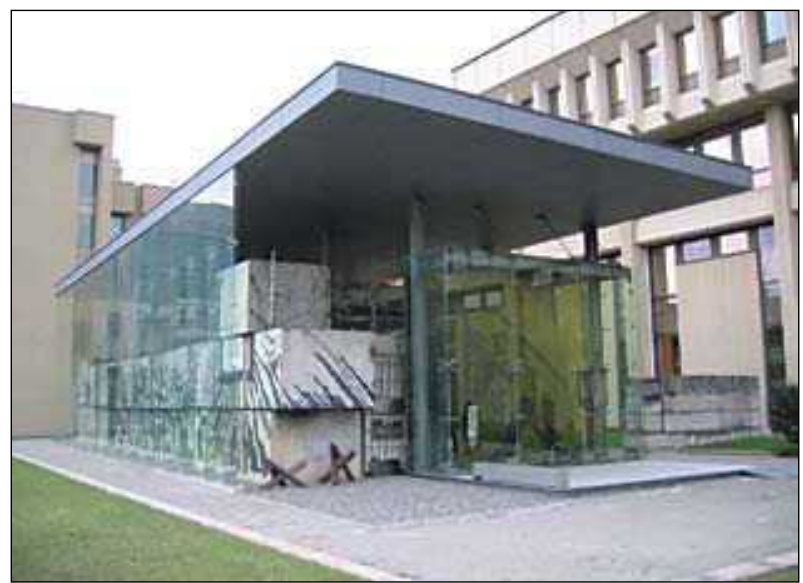

14 pav. Sausio 13 -osios memorialas. Archit. UAB Vilniaus architektūros studija, K. Kisielius, J. Dagelis, 2008

Fig. 14. Memorial to 13th of January. Architects: "UAB Vilniaus architektūros studija", K. Kisielius, J.Dagelis, 2008

tinimų liekanas nuo ardančio atmosferos poveikio ir jas integruojant formuoti daugiafunkcę aplinką maldai ir susikaupimui, taip pat ịrengti vietą ekspozicijai, skirtai nepriklausomybès atkūrimo įvykiams atminti. Panaudojant minimalius stogo ir stiklinių sienų sprendinius buvo siekiama sukurti gyvos atminties erdvę. Memorialas vertintinas nevienareikšmiškai dèl kelių priežasčių. Visų pirma, svarbiausiam šios architektūrinès kompozicijos elementui - stogui - nepavyko suteikti utilitarią paskirtị peržengiančio pavidalo. Antra, nuo $1991 \mathrm{~m}$. ìvykių likusių gynybinių užtvarų apžiūrą apsunkino jas saugančių stiklo plokštumų kuriami atspindžiai ir beremių fasadinių sistemų konstrukcinių elementų gausa. Tačiau labiausiai atminties koplyčios idèją kompromituoja tai, kad i ją nèra galimybès laisvai patekti - atminties erdvè tapo apsaugota nuo atminties puoselètojų. Tai, be abejo, nèra architektų, bet bendros Lietuvos atminties kultūros problema.

\section{Išvados}

1.Vilniaus miesto centrinės dalies aikštėse plètojami atminties ịprasminimo sprendiniai rodo, kad šiandieninẻje Lietuvoje paminklai yra neabejotinai svarbūs reprezentacinès kultūros atributai, esmingai veikiantys svarbiausių miesto aikščių statusą, funkcinę sandarą ir meninius pavidalus, taip pat ženklinantys visuomenëje vyraujančias vertybines nuostatas, požiūrị $\mathfrak{i}$ praeitị ir dabartį.

2. Pastaruju $15 \mathrm{~m}$. laikotarpiu Gedimino prospekto aplinkoje esančiose aikštėse pastatytų paminklų ir konkursinių projektų analizė leidžia įžvelgti siekị 
atskirų paminklų naratyvus koreliuoti tarpusavyje vystant Didžiuosius pasakojimus. Lietuvos istorinès raidos pikinius reiškinius ir ryškiausias asmenybes ị nuoseklią chronologinę progresiją sudèlioja Gedimino aikštèje ir jos aplinkoje pastatyti valstybingumą kūrusių ir plètojusių viduramžiais valdovų paminklai, V. Kudirkos aikštėje - Lietuvos nacionalinio atgimimo XIX a. antroje puseje - XX a. pradžioje judèjimo vieno svarbiausių palaikytojų paminklas, Lukiškių aikštėje planuojamas statyti Laisvés kovų (akcentuojant pokario rezistenciją ir jos aukas) paminklas ir Nepriklausomybès aikštejje stovintis Sausio 13-osios memorialas. Trys iš septinių Lukiškių aikštės sutvarkymo konkurso antro turo projektinių siūlymų, akcentuojančių skersinę aši, brèžiamą nuo Tauro kalno per aikštę iki aukštuminių pastatų koncentracijos zonos dešiniajame Neries krante, irgi priskirtini sprendinių tipui, išryškinančiam miesto plane simbolines galios ašis ir ženklinančiam istoriją kaip linijišką interpretacinę struktūrą.

3. Didžiojo kunigaikščio Gedimino, V. Kudirkos paminklų ir architektūrinès aplinkos bei struktūrinių formantų aikščių, kuriose jie stovi, kompozicinių sąsajų schematiškumas leidžia daryti išvadą, kad vis dar ịprasta suvokti paminklus kaip uždaras ir gana autonomiškas aplinkos atžvilgiu formas, kuriomis sprendžiami istorijos ženklinimo urbanistineje aplinkoje klausimai, nebūtinai susiję su tam tikros visuomeninès erdvès meninès ir funkcinès visumos inovatyviu plètojimu, atitinkančiu šiandienos visuomenès poreikius.

4. Šiandieninè paminklinė raiška Lietuvoje daugiausia grindžiama konservatyviomis ideologinemis nuostatomis ir plètojama remiantis konvencionaliais galios ženklinimo sprendiniais ir vaizdiniais. Paminklai realizuojami veikiant klasikinei europietiškai užsakomųjų kūrinių, skirtų visuomeninėms erdvèms, tradicijai, kuri Lietuvos kontekste buvo pradèta puoselèti XX a. pirmoje pusèje, o savaip išplètota sovietiniais metais. Tarp naujausių paminklų (ir projektinių siūlymų) didžiąją dali sudaro dominuojančio ir orientuojančio tipo, akcentuojantys geometrinį erdvès centrą arba centrinę aši, vertikaliai komponuojami, derinantys archetipines architektūrines formas ir realistinę vaizduojamąją skulptūrą sprendiniai.

5. V. Kudirkos paminklo ir Sausio 13-osios memorialo kompozicijose buvo panaudotos moderniai architektūrai būdingos, tačiau lietuviškuose paminkluose anksčiau nenaudotos medžiagos ir technologiniai sprendimai (pvz., stiklo konstrukcijos, lazerio apšvie- timas), tačiau jų harmonizuoti su kitais ženklinančiais pavidalais nepavyko.

6. Nors Vilniaus miesto centrinės dalies aikštėse pastarųjų penkiolikos metų laikotarpiu pastatyti paminklai meninès kalbos naujumu nepasižymi, tačiau tarp konkursinių projektų esama ir inovatyvių paminklo koncepcijos ribas praplečiančių pasiūlymų. Net trijuose Lukiškių aikštės konkurso antrojo turo projektuose paminklas nebèra skulptūrinis akcentas, paverčiantis aikštę paminklo erdve, o atvira forma, apimanti visus aikštès struktūrinius komponentus ir realizuojama kaip erdvess ir patirčių kūrimo priemonių visuma.

\section{Literatūra ir šaltiniai}

Bachelard, G. 1993. Svajonių džiaugsmas. Vilnius: Vaga.

Bauman, Z. 2002. Globalizacija: pasekmès žmogui. Vilnius: Strofa.

Benevolo, L. 1998. Europos miesto istorija. Vilnius: ALF / Baltos lankos.

Beresnevičius, G. 1991. Gediminas ir Lisdeika, iš Almanachas „Miestelenai“. Vilnius: Taura, 85-93.

Čiurlionienè, I. 2008. Vilniaus miesto plano transformacijos XVIII a. pab. - XIX a., Urbanistika ir architektūra XXXII(1): $3-11$.

Dumalakas, A. 2008. Pasukti Gedimino paminklo dèl lèšu stokos nepavyko, Lietuvos rytas, Sostinés priedas [interaktyvus] [žiūrèta 200904 10]. Prieiga per internetą: <http:// www.lrytas.lt/-12210267791220007262-pasukti-gedimino-paminklo-d\%C4\%971-1\%C4\%97\%C5\%A1\%C5\%B3stokos-nepavyko.html>.

Jankevičiūtè, G. 2004a. Monumentalioji skulptūra. Pasmerkta nemirtingumui? Iš Seminaro „Europos erdvé: naujausios žinios apie genius loci "pranešimu rinkinys (sudarè E. Lubytè). Vilnius: Lietuvos dailès muziejus, 34-37.

Jankevičiūtè, G. 2004b. Dailès gyvenimas Lietuvos Respublikoje 1918-1940: monografija. Kaunas: Nacionalinis M. K. Čiurlionio muziejus.

Koolhaas, R. 1995. S, M, L, XL. Rotterdam.

Kostkevičiūtè, I. 1997. Žmogus V. Kašūbos kūryboje. Vilnius: REGNUM fondas.

Kudirkos paminklo konkurso salygos [interaktyvus] [žiūrèta 200905 12]. Prieiga per internetą: <http://www.kudirkosfondas.lt/ >.

Marling, G. 2008. Designing the experience city - the role of hybrid cultural projects, Nordic Journal of Architectural Research 20: 21-38.

Michalski, S. 1998. Public monuments. Art in Political Bondage 1870-1997. London: Reaktion Books Ltd.

Novickas, A. 2000. Skulptūriniai monumentai Vilniaus miesto aikštèse XIX a. ir XX a. sandūroje, Urbanistika ir architektūra XXIV(1): 11-23.

Petraitienè, I. 2004. Štrichai skulptoriaus Arūno Sakalausko portretui, Nemunas 29-470 [interaktyvus] [žiūrèta 200905 12]. Prieiga per internetą: $<$ http://test.svs.lt/?Nemunas;Number(110)>. 
Raven, A. 1993. Art in the Public Interest. Cambridge: Da Capo Press.

Rindzevičiūtè, E. 2005. Identitetas ir saugumas Lietuvos kultūros politikos diskursuose, iš Pažymètos teritorijos (sudarè R. Goštautienè, L. Jablonskienè). Vilnius: Tyto Alba, 11-31.

Santarcangeli, P. 1991. Centras, iš Almanachas „Miestelenai“: 77-84. Vilnius: Taura.

Šešelgis, K. 1997. Vilniaus miesto Lukiškių aikštès formavimo projektai, Urbanistika ir architektūra XXIV(2): 32-51.

Vyšniūnas, A. 2008. Lukiškių aikštė - socialinio užsakymo evoliucija. Paminklas laisvès kovų dalyviams ar simbolis „Laisve“"? Urbanistika ir architektūra XXXII(4): 201-220.

Winskowski, P. 2007. Ethical Factors in Spatial Environment, Urbanistika ir architektūra XXXI(1): 3-11.

Young, J. E. 1992. The Counter-Monument: Memory against Itself in Germany Today, in Art and the Public Sphere (Ed. by W. J. T. Mitchell). London, Chichago: The University of Chicago Press, 49-79.

Бринкман, А. Э. 1935. Площзад и монумент как проблема художественной формы. Москва.

Линч, К. 1986. Совершенная форма в градостроительстве. Москва: Стройиздат.

Морозов, И. 1999. Архитектурная герменевтика. Минск: Пеито.

Зитте, К. 1993. Художественные основы градостроительства. Москва: Стройиздат.

\section{RECENT MONUMENTS IN THE SQUARES OF THE CENTRAL PART OF VILNIUS}

\section{A. Novickas}

Abstract. The paper deals with the recent projects of monuments and their realization for the squares of the central part of Vilnius. The aim of the analysis is to reveal essential features of recent memorial designs and their influence on the form and content of specific public spaces. The analysis of recent designs for Arkikatedra, V. Kudirka and Lukiškès Squares is contextualized with the help of a brief review of historic monuments of Vilnius. Particular attention is paid to the semantic aspect of architectural monument composition, imagery, technologies and materials. A conclusion is drawn that recent memorial designs for public squares are based on conservative ideology, and its development is mostly limited to traditional means of expression and usage of power symbols. Nevertheless, there are indications of a growing number of design proposals that are directed toward attempts to broaden the concept of monumental art and to bring out innovative tendencies.

Keywords: monument, square, Vilnius, Gediminas Avenue, collective memory, signification, meaning, sociocultural context, new tendencies

\section{AUDRIUS NOVICKAS}

Doctor of the Humanities (architecture), Assoc Prof, Dept of Architectural Graphics, Vilnius Gediminas Technical University, Pylimo g. 26/Traku g. 1, LT-01132 Vilnius, Lithuania.

Teaching interests: fine arts, relationship of architecture and art, semantics of architecture. Research interests: design of public spaces, contemporary public art, semantics of architecture, art of collective memory, cross-disciplinary research. 